\title{
Variation in leukocyte counts of Sahiwal and Karan Fries cattle during acute thermal exposures
}

\author{
Prava Mayengbam*, T.C. Tolenkhomba, R.C. Upadhyay \\ National Dairy Research Institute, Karnal 132001, Haryana, India \\ Corresponding author: dr_prava@ @rediffmail.com
}

\begin{abstract}
The leukocyte counts of Sahiwal and Karan Fries (KF) crossbred cattle in response to acute thermal stress were investigated. Six numbers each of Sahiwal and KF were exposed to acute thermal stress at $40^{\circ} \mathrm{C}$ and $50 \%$ RH for $\mathbf{4 h}$ in a psychromatic chamber located at Karnal, India during the period when Tmax/Tmin was $30.80^{\circ} \mathrm{C} / 13.60^{\circ} \mathrm{C}$. Both the breeds responded differently at different intervals of exposure. In Sahiwal, lymphocyte count decreased from $67.48 \pm 2.44$ at $0 \mathrm{~h}$ to $59.39 \pm 1.06 \%$ after $2 \mathrm{~h}$, but increased neutrophil from $23.90 \pm 1.22$ at $\mathrm{O}$ h to $30.24 \pm 1.02 \%$ after $2 \mathrm{~h}$. In $\mathrm{KF}$, lymphocyte decreased from $65.95 \pm 3.06$ at $\mathrm{Oh}$ to $63.07 \pm 0.66 \%$ after $3 \mathrm{~h}$, while neutrophil count remained stable. Neutrophil-lymphocyte ratio increased in Sahiwal from $0.36 \pm 0.02$ at $0 \mathrm{~h}$ to $0.51 \pm 0.02$ after $3 \mathrm{~h}$ while in $\mathrm{KF}$ it was stable. Monocyte count dropped from $5.75 \pm 0.84$ at $0 \mathrm{~h}$ to $5.34 \pm 0.50 \%$ after $4 \mathrm{~h}$ in Sahiwal, and from $5.18 \pm 0.61$ at $0 \mathrm{~h}$ to $5.76 \pm 0.04 \%$ after $4 \mathrm{~h}$ in KF. Both the breeds had stable eosinophil counts ranging from $5.34 \pm 0.50 ; 4.82 \pm 0.45$ to $7.06 \pm 0.22 ; 5.765 \pm 0.04 \%$ and basophil counts ranging from 0 to $1 \%$ at different intervals of thermal exposure. Neutrophil-lymphocyte ratio revealed prompt and faster physiological adjustments in Sahiwal than KF while KF.
\end{abstract}

Keywords: Crossbred cattle, leukocyte, Sahiwal, Karan Fries, thermal stress.

\section{INTRODUCTION}

Thermal stress occurs due to any single or a combination of environmental factors when the effective temperature of the environment is higher than the animal's thermoneutral zone. The heat stress impinging on the animal causes a chain of physiological, anatomical and behavioural changes leading to a reduction in productive functions. The reduction of productivity with devastating economic consequences to the global dairy industry due to warm environment has been documented (Bernabucci et al., 2010).

Impacts of heat stress on bovine's immune system have been found to vary depending on the duration and severity of heat stress exposures (West, 2013). Physiologic leukocytosis has been found to associate with stress (Tornquist and Rigas, 2010). Indigenous cattle and crossbred cattle have been found to respond differently in different climatic conditions and exposures (Mayengbam and Upadhyay, 2014; Mayengbam et al., 2015; Mayengbam et al., 2017). The present study aims to study differ- ent response of indigenous cattle, Sahiwal and crossbred cattle Karan Fries (KF) in terms of its leukocytes profile.

\section{MATERIALS AND Methods}

Sahiwal and Karan Fries (Tharparkar X HolsteinFriesian) heifers numbering 6 each were selected from the herd maintained at National Dairy Research Institute (NDRI), Karnal, India. The animals were in the age group of 2 to 2.5 years and average body weight was $301.3 \pm 6.91 \mathrm{~kg}$. The animals were given a maintenance concentrate mixture at $1 \mathrm{~kg} /$ animal in addition to ad lib roughages and water as per Kearl's standard (Kearl, 1982). Concentrate mixture consisted of mustard cake, maize, wheat bran, rice bran, mineral mixture and salt. The CP and TDN in diet were $12 \%$ and $60 \%$ respectively.

The study was carried out during a period when Tmax/Tmin was $30.80^{\circ} \mathrm{C} / 13.60^{\circ} \mathrm{C}$. Sahiwal and Karan Fries heifers were placed in the psychrometric chamber (temperature and humidity controlled) for $4 \mathrm{~h}$ (from 9 am to $1 \mathrm{pm}$ ) maintained at $40 \pm 1^{\circ} \mathrm{C}$ and $50 \%$ relative hu- 
midity $(\mathrm{RH})$ for inducing acute heat stress. Prior to the start of the experiment all the animals were kept in the psychrometric chamber at the prevailing temperature for $4 \mathrm{~h}$ every day for 10 days to acclimatize to the chamber environment.

A few drops of venous blood were collected at $0,1,2$, 3 , and $4 \mathrm{~h}$ of heat exposure for total leukocyte count (TLC) and differential leukocyte count (DLC). TLC and DLC were performed by standard procedures as described by Jain (1986). A total of 200 cells were counted for DLC and was expressed as percentage (\%). Data were subjected to one-way ANOVA for statistical significance followed by Duncan's post hoc multiple comparisons to evaluate the differences between periods of exposures on all the parameters under the study and $p<0.05$ was accepted as statistically significant.

\section{RESULTS}

The TLC and DLC of Sahiwal and KF during acute thermal exposure are presented in Table 1. TLC of both Sahiwal and KF remained stable throughout the period of thermal exposure. Neutrophil and lymphocyte (\%) of Sahiwal increased significantly $(p<0.05)$ after $2 \mathrm{~h}$ of exposure which remained stable thereafter till $4 \mathrm{~h}$ (Table 1 ). In KF there was no significant change in neutrophil (\%) throughout the period of exposure while lymphocyte (\%) fluctuated at different intervals with significant difference found between 1 and $3 \mathrm{~h}$ of exposure (Table 1 ).

Monocyte (\%) of Sahiwal was stable till $3 \mathrm{~h}$ of exposure (Table 1). Significant decrease in monocyte (\%) was recorded after $4 \mathrm{~h}$ of exposure as compared to 0-2 $\mathrm{h}$ of exposures (Table 1). KF had significantly higher monocyte (\%) after $3 \mathrm{~h}$ of exposure as compared to $0 \mathrm{~h}$ and $1 \mathrm{~h}$ of exposure while (Table 1). Eosinophil (\%) of both Sahiwal and KF was not influenced by thermal exposure (Table 1).
Basophil (\%) was same in both the breeds which were found to be $0-1 \%$ at different intervals of thermal exposure.

There was no significant change in neutrophil to lymphocyte ratio in case of KF while Sahiwal was found to increase its neutrophil to lymphocyte ratio after $2 \mathrm{~h}$ of exposure.

\section{DISCUSSION}

White blood cells or leukocytes are fundamental cells in immune defense. The number of leukocytes in the blood constitutes only a small percentage of the total population and undergoes wide fluctuation (Ronald et al., 2014). Physiologic leukocytosis has been found to associate with stress, excitation, fear, exercise, or parturition (Lynch et al., 2010). A stress leukogram is characterized by neutrophilia, lymphocytopenia, eosinopenia, and occasionally monocytosis (Jones and Allison, 2007; Tornquist et al., 2010). Increase in neutrophil to lymphocyte ratio has been indicated to be a good index for presence of stress in cattle due to weaning stress, parturition stress, etc. (Lynch et al., 2010; Loughlin et al., 2011).

In the present study, TLC did not reveal any sign of stress in both the breeds of cattle. The Sahiwal heifers showed neutrophilia and lymphocytopenia which reflected to higher neutrophil to lymphocyte ratio after $2 \mathrm{~h}$ of thermal exposure while KF showed no such changes in the present study. It could be due to prompt physiological response of Sahiwal as compared to KF. In the previous reports of the present authors it was reported that Sahiwal heifers had higher thermal tolerance indices than KF (Mayengbam et al., 2018) with higher heat load due to acute thermal exposure in KF than Sahiwal (Mayengbam and Upadhyay, 2014). The present finding could indicate the temporary physiological adjustments

Table 1: Total leukocyte count and differential leukocyte count of Sahiwal and Karan Fries during acute thermal exposure.

\begin{tabular}{|l|l|c|c|c|c|c|}
\hline Parameter & Breed & $\mathbf{0 ~ h}$ & $\mathbf{1 ~ h}$ & $\mathbf{2 ~ h}$ & $\mathbf{3 ~ h}$ & $\mathbf{4 ~ h}$ \\
\hline \multirow{2}{*}{ TLC $\left(\mathrm{x} 10^{3} / \mu \mathrm{l}\right)$} & Sahiwal & $11.85 \pm 0.83$ & $12.17 \pm 0.88$ & $12.20 \pm 0.74$ & $12.13 \pm 0.59$ & $12.70 \pm 0.72$ \\
\cline { 2 - 7 } & KF & $12.52 \pm 0.59$ & $12.28 \pm 0.69$ & $12.23 \pm 0.38$ & $12.30 \pm 0.35$ & $12.08 \pm 0.68$ \\
\hline \multirow{2}{*}{ Lymphocyte (\%) } & Sahiwal & $67.48 \pm 2.44^{\mathrm{b}}$ & $67.43 \pm 1.99^{\mathrm{b}}$ & $59.39 \pm 1.06^{\mathrm{a}}$ & $61.60 \pm 1.81^{\mathrm{a}}$ & $61.65 \pm 0.20^{\mathrm{a}}$ \\
\cline { 2 - 7 } & KF & $65.95 .2^{\mathrm{ab}}$ & $66.50 \pm 0.73^{\mathrm{b}}$ & $63.99 \pm 1.03^{\mathrm{ab}}$ & $63.07 \pm 0.66^{\mathrm{a}}$ & $63.15 \pm 1.73^{\mathrm{a}}$ \\
\hline Neutrophil (\%) & Sahiwal & $23.90 \pm 1.22^{\mathrm{a}}$ & $23.95 \pm 0.86^{\mathrm{a}}$ & $30.24 \pm 1.02^{\mathrm{b}}$ & $29.47 \pm 1.23^{\mathrm{b}}$ & $30.34 \pm 0.11^{\mathrm{b}}$ \\
\cline { 2 - 7 } & KF & $26.79 \pm 4.09$ & $26.90 \pm 0.18$ & $28.71 \pm 1.22$ & $28.54 \pm 0.60$ & $29.52 \pm 0.63$ \\
\hline Monocyte (\%) & Sahiwal & $5.75 \pm 0.84^{\mathrm{b}}$ & $5.84 \pm 0.74^{\mathrm{b}}$ & $7.06 \pm 0.22^{\mathrm{b}}$ & $6.28 \pm 0.78^{\mathrm{b}}$ & $5.34 \pm 0.50^{\mathrm{a}}$ \\
\cline { 2 - 7 } & KF & $5.18 \pm 0.61^{\mathrm{a}}$ & $4.82 \pm 0.45^{\mathrm{a}}$ & $5.25 \pm 0.08^{\mathrm{ab}}$ & $5.76 \pm 0.04^{\mathrm{b}}$ & $5.23 \pm 0.60^{\mathrm{ab}}$ \\
\hline Eosinophil (\%) & Sahiwal & $2.88 \pm 0.42$ & $2.78 \pm 0.46$ & $3.30 \pm 0.08$ & $2.65 \pm 0.39$ & $2.67 \pm 0.39$ \\
\cline { 2 - 7 } & KF & $2.08 \pm 0.51$ & $1.77 \pm 0.44$ & $2.00 \pm 0.41$ & $2.64 \pm 0.42$ & $2.10 \pm 0.51$ \\
\hline \multirow{2}{*}{ Basophil (\%) } & Sahiwal & $0-1$ & $0-1$ & $0-1$ & $0-1$ & $0-1$ \\
\cline { 2 - 7 } & KF & $0-1$ & $0-1$ & $0-1$ & $0-1$ & $0-1$ \\
\hline \multirow{2}{*}{ :L } & Sahiwal & $0.36 \pm 0.02^{\mathrm{a}}$ & $0.36 \pm 0.01^{\mathrm{a}}$ & $0.51 \pm 0.02^{\mathrm{b}}$ & $0.48 \pm 0.02^{\mathrm{b}}$ & $0.49 \pm 0.01^{\mathrm{b}}$ \\
\cline { 2 - 7 } & KF & $0.41 \pm 0.05$ & $0.41 \pm 0.00$ & $0.45 \pm 0.02$ & $0.45 \pm 0.01$ & $0.47 \pm 0.01$ \\
\hline
\end{tabular}

Values with different superscripts in the same row differ significantly at $\mathrm{p}<0.05$ 
adopted by Sahiwal without affecting physiological indices and thermal heat load during acute thermal exposure unlike KF.

The most common causes for neutrophilia are chronic inflammation and stress (Jones and Allison, 2007). Since these heifers were clinically healthy neutrophilia in Sahiwal indicated activation and involvement of these cells during acute thermal stress. Monocytosis was also evident in acute thermal stressed Sahiwal heifers after $4 \mathrm{~h}$ of exposures and $\mathrm{KF}$ after $3 \mathrm{~h}$ of exposures. These differences could indicate differences in the mechanisms adopted by different breeds of cattle.

The present study indicated active involvement of leukocytes during physiological adjustments of both indigenous and crossbred cattle during acute thermal exposures. A prompter response of different leukocytes of Sahiwal was evident during acute thermal exposures without causing significant change in the total leukocyte number.

\section{ACKNOWLEDGEMENT}

The authors are grateful to ICAR-Network Project on Impact, Adaptation and Vulnerability of Indian Agriculture to Climate Change and ICAR-NDRI, Karnal for financing the experiment and providing experimental animals respectively.

\section{REFERENCES}

Bernabucci, U., Lacetera, N., Baumgard, L. H., Rhoads, R. P., Ronchi, B., Nardone, A. (2010). Metabolic and hormonal adaptations to heat stress in domesticated ruminants. Animal, 4, 1167-1183.

Jain, N.C. (1986). Schalm's Veterinary Haematology. $4^{\text {th }}$ edn. WB Saunders and Company, Philadelphia.

Jones, M.L., Allison, R.W. (2007). Evaluation of the ruminant complete blood cell count. Veterinary Clinics of North America: Food Animal Practice, 23, 377-402.

Kearl, L.C. (1982). Nutrient Requirements of Ruminants in Developing Countries. International Feedstuffs Institute, Utah Agricultural Experiment Station, Utah State University Logan, Utah USA.

Mayengbam, P., Upadhyay, R.C. (2014). Heat shock protein 72 expression of Sahiwal and Karan Fries during thermal stress. Indian Journal of Dairy Science, 67, 147-153.

Mayengbam, P., Tolenkhomba, T.C., Upadhyay, R.C. (2018). Expression of Mn-SOD and Cu,Zn-SOD of Sahiwal and Karan Fries in response to acute heat exposure. Indian Journal of Animal Sciences, 88, 181-185.

Ronald, L., Drillich, M., Iwersen, M. (2014). Hematology as a diagnostic tool in bovine medicine. Leonie Journal of Veterinary Diagnostic Investigation, 26, 592-598.

Tornquist, S.J., Rigas, J. (2010). Interpretation of ruminant leukocyte responses. In: Schalm's Veterinary Hematology, ed. Weiss DJ, Wardrop KJ, $6^{\text {th }}$ editon. Wiley, Ames, IA., pp. 307-313.

West, J.W. (2003). Effects of heat-stress on production in dairy cattle. Journal of Dairy Science, 86, 2131-2144. 